\title{
Yield to the Night
}

\author{
MELANIE WILLIAMS
}

$\mathbf{J}$

EAN-LUC GODARD once remarked that all you need to make a film is 'a girl and a gun' and the opening sequence of Yield to the Night (J. Lee Thompson, I956) looks like a textbook illustration of his axiom. The girl is Mary Hilton, played by Diana Dors, who whips out the gun from her handbag and promptly shoots the woman she holds responsible for her lover's suicide. As a result, she finds herself convicted for murder and sentenced to death. Most of the film's action takes place in Mary's condemned cell as she waits to hear if her appeal has been successful and relives her doomed love affair with Jim (Michael Craig) that led to her crime passionel and her arrest. The film, unusually, does not have a happy ending: there is no last-minute reprieve for Mary. The film concludes as she is led away to the gallows.

Yield to the Night is often mentioned in connection with the contemporary case of Ruth Ellis, the last woman to be hanged in Britain. Although the film's scenario has a number of similarities to the Ellis case (a glamorous blonde murderess, a shooting), it is not, as is sometimes stated, based on it. The screenplay had been written two years before, and the film's appearance in the wake of Ellis's execution was coincidental. Nonetheless, this was a film that sought to enter the contemporary public debate on hanging, and to argue the abolitionist case to as many people as possible, through the medium of popular commercial cinema. What is particularly interesting about Yield to the Night is that it does not deal with a miscarriage of justice, like the later American anti-hanging film I Want to Live! (Robert Wise, I958). Mary Hilton is definitely guilty of her crime but the film still maintains that it is wrong for the state to hang her. To make a clear case against capital

\footnotetext{
I teach film studies at the University of Hull. I have written on British film for the Quarterly Review of Film and Video, the Journal of Popular British Cinema and the Journal of Gender Studies and I am currently completing a doctorate on the representation of women in the r95os films of J. Lee Thompson. This interest sprang from spending countless afternoons watching the Channel 4 matinee when I should have been doing something more constructive with my time. I also harbour a secret crush on Stanley Baker, especially in Hell Drivers. Melanie Williams
} 
punishment, director J. Lee Thompson argued that 'you must take somebody who deserves to die, and then feel sorry for them and say this is wrong'.

However, the film is far from being a straightforward statement of social protest on the part of its makers, which is partly due to the casting of Diana Dors, a notorious and flamboyant British film personality of the 1950 , in the role of Mary Hilton. Hailed as the only sex symbol Britain has produced since Lady Godiva, Diana Dors was a precocious teenager who had made her first film appearance at the age of 15 as a spiv's mistress in The Shop at Sly Corner (George King, 1946). By 1954, questions were asked in the House of Commons about her excessive consumerism (her most notable extravagance being a powder-blue Cadillac), and in 1955 she glided down the grand canal in Venice wearing only a made-to-measure mink bikini (Dors later admitted it was actually made from rabbit fur) as a film festival publicity stunt. And yet, the very next year, here was Britain's glitziest star discarding the persona of the glamorous starlet in favour of the serious actress, willing to swap mink for dowdy prison uniform and to let her immaculately dyed platinum hair grow out to show its dark roots for the role. This aspect of the film was one that fascinated the critics of the time, whose reviews of Yield to the Night are peppered with remarks about the change in her appearance, threatening to overshadow the ostensible point of the film, the plea for the abolition of hanging.

The style adopted by J. Lee Thompson to tell this story is also significant. Although he sought the greatest verisimilitude in the depiction of the condemned cell and what goes on in it, the film eschews the documentarystyle realism that might be seen as the natural companion of this kind of attention to detail. Instead, Thompson opts for a melodramatic, expressionistic film style which makes use of oblique angles, strange compositions and unnerving extreme close-ups, all of which dislocate the film from any simple 'realist' aesthetic. The realism of the film is a subjective, psychological realism, suggesting the strange and fearful state of mind of the person who knows she will die in a matter of days.

In fact, what gives Yield to the Night its emotional force is how the monumental melodrama of Mary, having to face her imminent death, is played out against a backdrop of banal reality and bureaucratic ritual. The film gives a strong feeling of the absurdity of Mary's situation: the friendly inconsequential chit-chat with the prison wardens who teach her to play chess, change the dressing on her blister and make sure she is well fed when the same women will lead her to her death in less than a week. It is the cinematic equivalent of George Orwell's famous essay on witnessing a hanging where 
it is not until he sees the condemned man, on the way to the gallows, walk around a puddle to avoid getting his feet wet, a tiny inconsequential moment of futility, that Orwell realises the immensity of what is about to happen.

When there was a parliamentary bill to abolish the death penalty in the House of Lords, Gerald Gardiner QC and Arthur Koestler organised a special screening of Yield to the Night. Only six of the invited peers came along. The bill was defeated and capital punishment was not repealed until 1965. The film, despite its aim to be commercial, was a box-office flop. As an attempt to intervene in the debate on hanging, Yield to the Night might be judged a failure. But as the high point of both Dors's and Thompson's respective careers, by their own admission, and a brave attempt to tackle a pressing social issue, it remains one of the most interesting British films of the decade. 